Author: C Okpaluba and L Juma

THE PROBLEMS OF PROVING ACTUAL OR APPARENT BIAS: AN ANALYSIS OF CONTEMPORARY DEVELOPMENTS IN SOUTH AFRICA

ISSN 1727-3781

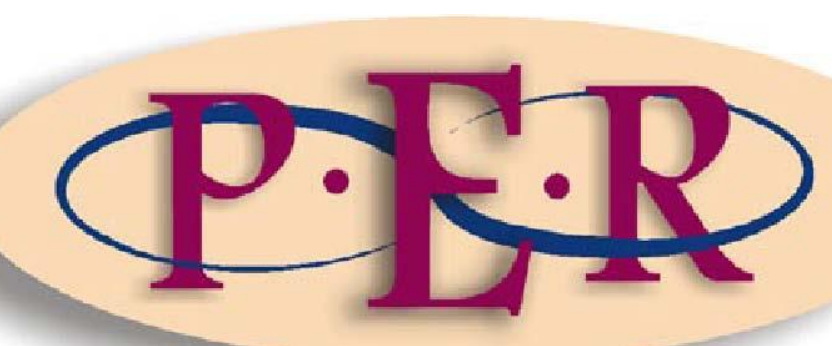

2011 VOLUME 14 No 7

http://dx.doi.org/10.4314/pelj.v14i7.2 


\title{
THE PROBLEMS OF PROVING ACTUAL OR APPARENT BIAS: AN ANALYSIS OF CONTEMPORARY DEVELOPMENTS IN SOUTH AFRICA
}

\author{
${ }^{\star}$ C Okpaluba \\ ** Juma
}

\section{Introduction}

The major problem associated with allegations that a judge was biased or perceived to have been prejudiced is the inability of the complainant to prove the facts of adjudicative partiality. It is often impossible to determine with any measure of precision the state of mind of an adjudicator who has rendered a verdict. Thus, actual bias is an elusive proposition. Accordingly, the courts take the position that an appearance of impartiality is in itself an essential component of procedural fairness. Even so, the threshold of finding perceived bias is as high as where actual bias is alleged. Whenever an allegation of bias or a reasonable apprehension of bias is made, the adjudicative integrity not only of the individual judge but of the entire administration of justice is called into question. The court must, therefore, consider the matter very carefully before making a finding. ${ }^{1}$

In order to ensure that fairness in the conduct of regular courts and administrative tribunals is maintained, the courts ask the question whether or not a reasonably informed observer would reasonably perceive bias on the part of the officer adjudicating the issue. ${ }^{2}$ Clearly, therefore, unless the individual judge reveals by way of utterances or through conduct the inner working of her mind, it could be difficult to

\footnotetext{
Chuks Okpaluba, LLB, LLM, PhD Adjunct Professor, Nelson Mandela School of Law, University of Fort Hare. E-Mail: okpaluba@yahoo.co.uk.

** Laurence Juma, LLB, LLM, MA, LLD Associate Professor, Faculty of Law, Rhodes University. EMail: I.juma@ru.ac.za.

1 See eg $R v$ (DS) 1997151 DLR $\left(4^{\text {th }}\right)$ 193; Wewaykum Indian Band $v$ Canada 2003231 DLR $\left(4^{\text {th }}\right)$ 1 (Wewaykum); Ultracuts Franchises Inc v Wal-Mart Canada Corp 2005 MBQB 222 (CanLII) para 17.

2 Per Cory J, Newfoundland Telephone Co v Board of Commissioners of Public Utilities 199289 $\operatorname{DLR}\left(4^{\text {th }}\right) 289297$ (Newfoundland Telephone).
} 
guess what the judge, as a human being, has in mind. ${ }^{3}$ Robert Stevens thus rightly describes impartiality as an ephemeral concept which has eluded both philosophers and psychologists as to its real meaning. ${ }^{4}$ Much reliance is therefore placed on visible manifestations of impartiality. ${ }^{5}$ The answer to the question of whether a judge is biased or her judgment tainted with the elements of bias would ultimately rest on subjective human conjecture or perception.

However, public perception that a hearing was not fair would not per se be a ground upon which a court can set aside a hearing for apparent bias in the absence of its being reasonably entertained by the applicants and attributed to the adjudicator. ${ }^{6}$ Similarly, a general perception without particularity held by a group that professional judges are inherently prejudiced against a class of litigants may not suffice. ${ }^{7}$ Proof of apprehension of bias is made easier if it can be shown that the adjudicator has come to adjudication with a baggage of known or ascertainable relationships such as kinship or association (friendly or hostile) in professional, business or other pursuits

3 President of the Republic of South Africa v South African Rugby Football Union 19994 SA 147 (CC) para 35 (SARFU 2); Newfoundland Telephone Co $v$ Newfoundland (Board of Commissioners of Public Utilities) 19921 SCR 623 636; $R$ v Bow Street Magistrate; Ex parte Pinochet [No 2] 20001 AC 119 (Pinochet [No 2]) 138 (Pinochet [No 2]).

4 Stevens 1999 Oxford Journal of Legal Studies 379.

5 The composition of the tribunal is one sure visible manifestation. Where, therefore, certain members of a domestic disciplinary tribunal of a political party who sat to hear allegations of misconduct against a co-member subsequently participated in the panel that heard the member's appeal upon their decision to expel him, the Transkei Division of the High Court could not imagine a clearer breach of the rule against bias - Mafongosi v United Democratic Movement 20025 SA 567 (Tk).

6 In Derby-Lewis $v$ Chairman, Amnesty Committee of the Truth and Reconciliation Commission 20013 SA 1033 (C) 1067C-D it was argued that in the light of statements made by various persons and groups before the amnesty hearing for the murder of Chris Hani, there was a public perception that their hearing was not a fair hearing. Although the applicants did not allege bias or prejudice on the Committee members, they asked the court to replace the Committee's finding with theirs rather than remitting the matter back to the Committee. It was held that "a public perception would not be a good ground for substituting our own verdict, if a remittal was otherwise indicated. The applicants would at least have to show that they reasonably perceive bias on the part of the Amnesty Committee to which their applications are remitted.... They have already accepted that at least one Amnesty Committee (being the Committee a quo) was unbiased towards them. On that premise, they must accept that there may be other unbiased Committees." Such reasonable perception was legitimately entertained in Bam-Mugwanya $v$ Minister of Finance and Provincial Expenditure, Eastern Cape 20014 SA 120 (Ck) paras 34-35 where a member of the Provincial Tender Board misrepresented to the Board that she had no interests in the transport services subject of the tender whereas the member and her brother had direct interest in the passenger transport industry. It was held that it was a clear-cut instance of a situation where she ought to have recused herself from the tender process in its entirety. And having not done so, her participation in the tender process tainted the entire exercise with bias. CUPE v Ontario (Minister of Labour) 2003226 DLR (4th) 193 paras 199-204 per Binnie J. 
with one of the parties in court. ${ }^{8}$ It may be that the adjudicator has pecuniary interest in the subject matter of dispute $;^{9}$ or that she has uttered words or in some other manner exhibited an obviously prejudicial attitude that may alert a party thereby prejudiced of the danger that he might not obtain even-handed justice from the judge. $^{10}$ In the absence of any of these conceivable factors, bias or impartiality falls to be determined from the circumstances of the case. Incidentally, such a determination cannot be founded on an adjudicator's error of interpretation, or on her application of the law to the facts before court. ${ }^{11}$ The bare fact that a judge has ruled against an applicant is not evidence sufficient to show the state of the judge's mind. It alone cannot support a claim of bias nor can it serve as evidence to impeach the legal quality of an otherwise well conducted judicial proceeding. ${ }^{12}$ Similarly, that a deadly legal point was forcefully made by the court during argument in a matter cannot give rise to an apprehension of bias in the eyes of the "reasonable, objective and informed litigant in possession of the correct facts." ${ }^{13}$

This article attempts to isolate the emerging approaches to the determination of actual or apparent bias in South Africa by analysing the jurisprudence on the subject. Its purpose is to indicate, albeit within the confines of available jurisprudence, the key factors that may influence the courts in their determination of whether or not adjudicative bias has occurred. Notably, therefore, the recent case of De Lacy and Another $v$ South African Post Office ${ }^{14}$ dictates the tone of this article, not so much because it has laid down principles unknown to this field of the law but for the novelty of the allegations and the manner in which they were delivered. The facts of De Lacy represent an excellent illustration of what an Australian Chief Justice once described as "fanciful and extravagant assertions and demands" in the pretext that justice

8 In Webb v The Queen 1994181 CLR 41 74, which involved the disqualification of a juror, Dean J identified four distinct, though overlapping categories of cases involving disqualification by reason of the appearance of bias: interest, conduct, association and extraneous information.

9 Instances of the disqualifying factors can be gleaned from: Wade and Forsyth Administrative Law 389-392; Okpaluba Right to a Fair Hearing 185-204; Devenish, Govender and Hulme Administrative Law and Justice 321-333; Burns and Beukes Administrative Law 305-307; Hoexter, Administrative Law 407-412; Devenish 2000 TSAR 399-408.

10 Cf Stainbank v South African Apartheid Museum at Freedom Park 2011 ZACC 20 (9 June 2011) (Stainbank).

11 Commissioner, Competition Commission v General Council of the Bar of South Africa 20026 SA 606 (SCA) para 16.

12 Cf Taku River Tlingit First Nation v Ringstad 2002211 DLR 89 (BCCA).

13 Take and Save Trading CC v Standard Bank of SA Ltd 20044 SA 1 (SCA) para 17 per Harms JA.

14 De Lacy v South African Post Office 2011 ZACC 17 (24 May 2011) (De Lacy). 
should not only be done but be seen to be done. ${ }^{15}$ Further, De Lacy has necessitated an analysis of those adjudicative guidelines articulated recently in Bernert $v A B S A$ Bank $L t d^{16}$ and other Commonwealth cases which invariably constitute obstacles in the way of applicants who dare come to court with outlandish claims of judicial partiality. It is one case that shows how difficult it is to prove an allegation of actual or perceived bias against a judge having regard to the objective standards of the fair-minded and informed observer, the presumption of impartiality, and the test for establishing bias.

Interestingly, De Lacy did not involve any of the common grounds upon which issues of bias often arise. ${ }^{17}$ The charges of bias were directed not only towards a single judge but towards the whole bench. It was not about their conduct of the proceedings but about their judgment. Incidentally, the claim of bias was made not in the complainants' original applications for leave but long after they had tried their luck elsewhere and failed. They (the complainants) neither claimed that the judges or any of them had pecuniary interest in a party in court, which was the principal objection in Bernert and the only issue before the Supreme Court of Appeal in Ndimeni v Meeg Bank Ltd (Bank of Transkei), ${ }^{18}$ nor did they allege that the judges, or any of them, had any other disqualifying interest or relationship, prior or on-going, with one or other party to the proceeding, or were directly or even remotely connected with the case in court. There was also no question of the improper composition of the court. The only similarity between De Lacy and $S v$ Basson $2^{19}$ lay in the extent to which the former involved alleged incorrect factual findings made by the court, something resembling one of the many issues of apprehended bias contested in the latter. Again, De Lacy has some link with Bernert insofar as the appellate court's factual findings were impeached in both cases. Nonetheless, neither the appellant in Basson 2 nor the applicant in Bernert based their apprehension of bias on inferences from the judgments of the trial court or the appeal court, respectively.

15 Per Barwick CJ, Stollery v Greyhound Racing Control Board 1972128 CLR 509 518-519.

16 Bernert v ABSA Bank Ltd 20113 SA 92 (CC) (Bernert).

17 See eg SARFU 2; SACCAWU v Irvin and Johnson Ltd 20003 SA 705 (CC) (SACCAWU).

18 Ndimeni v Meeg Bank Ltd (Bank of Transkei) 20111 SA 560 (SCA).

$19 S$ v Basson 200512 BCLR 1192 (CC) (Basson 2) para 30. 


\section{The bias allegations in De Lacy}

What makes De Lacy strikingly different from Basson 2 and Bernert is the wild nature of the allegations and the vehemence in the language of attack against the conduct of the judges of the Supreme Court of Appeal not during the proceedings but in their judgment. If the basis upon which apprehension of bias was made in SARFU $2^{20}$ was somewhat odd, then the allegations in De Lacy were not only bizarre - they were outrageous. Otherwise, how does a party who approaches the Constitutional Court on leave to appeal against the judgment of the Supreme Court of Appeal prove actual bias on the part of the entire bench based on judgment delivered by that court? How can the answer be ascertained from the allegation that the court's judgment was not delivered impartially and without favour or prejudice? How could the appellants prove that the Justice of Appeal who had no financial or other relationship with any of the parties involved in the case deliberately distorted the facts of the case before him "for reasons best known" to him? Or that, at the instance of the same presiding judge, the court "decided to find against the applicants and in order to give effect to such decision, elected either to disregard the record for such purpose, or to apply interpretations to the record that are inconsistent with any reasonable understanding of the record." 21

Further allegations of premeditated bias against the Supreme Court of Appeal and the presiding judge were that they failed to distinguish between "facts and own interpretations thereof for the purpose of arriving at predetermined findings," and that they "disregarded" or "nullified" admitted facts to support predetermined findings. Moreover, the court "wilfully" ignored the evidence in a manner inconsistent with the record and proceeded to make at least 114 "grossly incorrect findings" in "a deliberate attempt" to justify the award of the tender to the opponent. Finally, counsel submitted that the applicants' complaint was not related to "findings of fact" but to the delivery of a judgment so lacking in impartially "that the integrity, probity and impartiality required of the judicial function were not displayed when the Court decided the appeal."22

20 SARFU 2.

21 De Lacy para 5.

22 De Lacy para 7. 
All of these invectives arose because the Supreme Court of Appeal had set aside an award of R60m made to the complainants by way of delictual damages by Hartzenberg J, who had found that there was fraud in the tender process. Adopting a different approach to the assessment of the facts, the appellate court found no fraudulent dealings in the award of tenders in which the applicants lost. ${ }^{23}$ As a consequence, it held that the case did not fit into the principles of delictual liability laid down in Minister of Finance and Others $v$ Gore $N^{24}$ and Steenkamp NO $v$ Provincial Tender Board, Eastern Cape. ${ }^{25}$ Incidentally, the allegations of bias did not appear in two previous applications for leave to appeal to the Constitutional Court made by the applicants, although they were the ground of their misconduct complaint against Nugent JA to the Judicial Service Commission. As the Deputy Chief Justice observed, apart from "the new label of actual or perceived bias, the direct access application too amounts to no more than a raging discontent over the factual findings of the Supreme Court of Appeal. Although the complaint is clothed in the apparel of actual or perceived bias, it rests on the same scathing attack of the Court's findings." ${ }^{26}$ The attitude of the appellant was understandable since the Constitutional Court deals only with constitutional matters which have been held to include allegations of judicial bias. ${ }^{27}$ But it does not entertain applications based purely on the dispute of facts with a lower court. ${ }^{28}$

23 South African Post Office $v$ De Lacy and Another 20095 SA 255 (SCA).

24 Minister of Finance $v$ Gore 20071 SA 111 (SCA). See the discussion in Okpaluba 2010 Lesotho Law Journal 1.

25 Steenkamp v Provincial Tender Board, Eastern Cape 20073 SA 121 (CC); Steenkamp v Provincial Tender Board, Eastern Cape 20063 SA 151 (SCA). See the discussion in Okpaluba and Osode Government Liability 133-160.

26 De Lacy para 57.

27 The Constitutional Court has, in two recent cases, reiterated the constitutional basis of its jurisdiction. In Stainbank paras 27 and 28, Khampepe $\mathrm{J}$ held that it is axiomatic that the question of whether or not a judicial officer should recuse himself or herself is a constitutional matter, as is the question of whether there was actual or reasonable apprehension of bias. It was held that the question of whether or not the judge should have recused himself and whether or not the applicant had a reasonable apprehension of bias therefore raises a constitutional matter. So too does the question of whether or not the High Court in this case was competent to make the impugned costs order. Again, in De Lacy para 47, Moseneke DCJ adverted to some of the reasons for this when he said: "Judicial authority is an integral and indispensible cog of our constitutional architecture. Our supreme law vests judicial authority in the courts - see s 165(1), 1996 Constitution. It commands that courts must function without fear, favour or prejudice, and subject only to the Constitution and the law. It follows that, at all times, the judicial function must be exercised in accordance with the Constitution. At a bare minimum this means that courts must act not only independently but also without bias, with unremitting fidelity to the law, and must be seen to be doing so." See further Bernert para 18; S v Basson 20051 SA 171 (CC) (Basson 1) paras 21-22; Basson 2 paras 24-5.

28 See eg S v Marais 20111 SA 502 (CC); S v Boesak 20011 SA 912 (CC). 


\section{$3 \quad$ Actual or apparent bias}

Whether the allegation relates to actual or apprehended bias, it is a serious matter which strikes at the validity and acceptability of the trial and its outcome. It is for this reason that once raised it must be dealt with first and foremost. The effect of a successful claim of bias results in a retrial of the matter. ${ }^{29}$ Actual bias is not often found in decided cases and therefore FS $v J J$ and Another ${ }^{30}$ should be considered an exception rather than the rule. ${ }^{31}$ However, it has been applied in the following two fact-situations: (a) where a judge has been influenced by partiality or prejudice in reaching a decision; and (b) where it has been demonstrated that a judge is actually prejudiced in favour or against a party. ${ }^{32}$ In the case of actual bias the disqualifying factor exists in fact, whereas in the case of apparent bias it does not. What is important in apparent bias is that the circumstances surrounding the adjudication are such that an inference can be drawn that the judge might be disposed towards one side or another in the matter in court. Case law shows that it is difficult to prove actual bias, ${ }^{33}$ apparently because of the subjectivity attendant upon it. That is why it is often unnecessary to investigate whether or not there was evidence to suggest that there was actual bias. ${ }^{34}$ It is enough that apparent bias be shown, that is, if

29 Per Kirby and Crennan JJ, Concrete Pty Ltd v Parramatta Design and Development Pty Ltd 2006 231 ALR 663 para 117.

30 FS $v$ JJ 20113 SA 126 (SCA) paras 41, 43 and 45. The appeal before the Supreme Court of Appeal was against a series of orders made by Kgomo JP in the Northern Cape High Court whereby he awarded custody to the respondents, the maternal grandmother of the child and her husband, an order which was at odds with those made by another Northern Cape Judge and the Western Cape High Court. In an application for leave to appeal against his findings, the trial judge expressed displeasure at the forum-shopping conduct of the applicants which, in his view, was done with the motive of avoiding the consequences of his orders. The Judge also admonished the applicants' lawyer and accused her of being mischevious. "Ms Deysel's attitude and conduct" he said, "is testimony to her utter ignorance of the Rules of Court and her abject discourtesy to this court by agitating non-appearance." The trial judge then invited the respondents to bring contempt proceedings against the applicants if his orders were not complied with. It is these utterances that the Supreme Court of Appeal found to evince bias on the part of the trial judge. According to Lewis $\mathrm{J}$, the language used was completely intemperate and was to be deplored. Further, by inviting a party to bring contempt proceedings against the other, the trial judge had "stepped into the arena" and was more concerned with "legal niceties" than with the "child's best interest".

31 See also McGuirk $v$ University of New South Wales 2010 NSWADTAP 66 paras 9 and 11; PCL Constructors Canada Inc v IABSORIW Local No 972008 CanLII 39763 (BCLRB) para 1.

32 In re Medicaments and Related Classes of Goods (No 2) 20011 WLR 700 (CA) 711 para 38; Davidson v Scottish Ministers 2004 UKHL 34 para 6.

33 On the contrary, Burns and Beukes Administrative Law 303-304 think it is the other way round. For them, it is generally "a simple matter to identify actual bias since the administrator will reflect a closed mind to the issues raised." In their view, "a reasonable suspicion of bias or perceived bias is rather more complex".

34 Per Cory J, Newfoundland Telephone 297; Locabail (UK) Ltd v Bayfield Properties Ltd 2000 QB 
viewed by the objective standard, which is that a reasonably informed person with knowledge of the facts would reasonably apprehend the possibility of bias in the circumstances. ${ }^{35}$

Most often, the parties start their pleading by discountenancing actual bias declaring that the integrity of the judge was not in doubt - so they base their case on the apprehension of bias. ${ }^{36}$ For instance, in McGonnell $v U K^{37}$ there was no suggestion that the Bailiff against whom an allegation of reasonable apprehension of bias was upheld was subjectively prejudiced or biased when he heard the applicant's planning appeal. Moreover, it was not alleged that his participation as Deputy Bailiff in the adoption of the development plan gave rise to actual bias on his part. Of course, where actual bias is shown to be present, the judge is disqualified and the proceeding is vitiated. Whether bias is actual or perceived is discernible from the facts of the case, the conduct, the utterances or the general disposition of the judge before or during the proceedings, his/her relationship with one or other of the parties or his/her interest in the outcome of the case before the court and the circumstances surrounding the entire case. ${ }^{38}$

The jurisprudence that has developed out of the principle of impartiality or the rule against bias is such that the courts do not insist on the proof of actual bias on the part of the judge, since the appearance or a reasonable apprehension of bias, if

451472 (Locabai).

35 Per Lord Brown, R (Al-Hasan) v Secretary of State for the Home Department 200519 BHRC 282 (HL) 287 para 37; Granpré J, Committee for Justice and Liberty v National Energy Board 19781 SCR 369 (SCC) 393. Vakuata v Kelly 1989167 CLR 568 (HCA) is another example. The trial judge had made statements critical of the evidence given by defendant's medical experts in previous cases. The Australian High Court held that although no case of actual bias was made out against the judge, the remarks made by him would have excited in the minds of the parties and in members of the public a reasonable apprehension that the judge might not bring an unprejudiced mind to the resolution of the matter before him.

36 In Davidson v Scottish Ministers 2004 UKHL 34 paras 5 and 7, the appellant was at pains to disclaim any challenge to the personal honour or judicial integrity of Lord Hardie. He lodged an attack on the interlocutors made by the Scottish Extra Division for apparent bias and want of objective impartiality on the ground of Lord Hardie's participation in the making of the orders as he was the Lord Advocate who not only supported but also made a speech promoting the amendment to the Crown Proceedings Act 1947 which prohibited the award of injunctive remedies against Scottish Ministers.

37 McGonnell v UK 20008 BHRC 56.

38 On interests, relationships and associations capable of disqualifying a judge from sitting and hearing a case as a result of apprehension of partiality see e.g. Dimes $v$ Grand Junction Canal Co 18523 HL Cas 759; Liebenberg v Brakpan Liquor Licensing Board 1944 WLD 52; Rose $v$ Johannesburg Local Road Transportation Board 19474 SA 272 (W); Turner v Jockey Club of SA 19743 SA 644 (A); S v Bam 19724 SA 41 (E); Barnard v Jockey Club of SA 19842 SA 35 (W). 
proved, is enough to vitiate the proceedings. ${ }^{39}$ As Lord Nolan said in Pinochet [No2], "where the impartiality of a judge is in question the appearance of the matter is just as important as the reality." ${ }^{40}$ Thus, "it is no answer for the judge to say that he is in fact impartial, that he abided by his judicial oath and there was a fair trial. The administration of justice must be preserved from any suspicion that a judge lacks independence or that he is impartial. If there are grounds sufficient to create in the mind of the reasonable man a doubt about the judge's impartiality, the inevitable result is that the judge is disqualified from taking any further part in the case. No further investigation is necessary, and any decisions he may have made cannot stand." ${ }^{41}$

But as already noted, actual bias is a rare occurrence. Parties seeking disqualification will therefore rely invariably on the apprehension of bias, and may, in fact, acknowledge from the outset the non-existence of actual bias. It is in this regard that the Supreme Court of Canada has identified three distinct implications of a party's saying to the court that she is not alleging actual bias. ${ }^{42}$ First, actual bias need not be established because the reasonable apprehension of bias can be viewed as a surrogate for it. Secondly, the party might be conceding that the judge acted in good faith and was hence not consciously relying on inappropriate perceptions, but was nevertheless unconsciously biased. For, as Lord Goff stated in $R \vee$ Gough $^{43}$ bias "is or may be an unconscious thing and a man may say that he was not actually biased and did not allow his interest to affect his mind, although, nevertheless, he may have allowed it unconsciously to do so. The matter must be determined upon the probabilities to be inferred from the circumstances in which the

39 Per Lord Denning MR, Metropolitan Properties Co (FGC) Ltd v Lannon 19691 QB 577599 "the court will not inquire whether [the judges] did, in fact, favour one side unfairly". Neither will they "shrink from that task if necessary" although it will hardly be necessary where the allegation is reasonable apprehension - EH Cochrane Ltd v Ministry of Transport 19871 NZLR 146 (CA) 153 per Cooke P.

40 Pinochet [No 2] 19991 All ER 577 592h. Along this line of reasoning, O'Linn J of the High Court of Namibia had to recuse himself from the trial in S v Dawid 19911 SACR $375(\mathrm{Nm})$ even though he found no atom of truth in the allegation that there had been actual bias on his part against the accused arising from his adverse finding on the credibility of the accused as a witness in another case. However, since he could not convince himself that the accused would not harbour a reasonable fear that owing to his earlier finding, he would not be biased in favour of finding that the accused's evidence in this case would also be rejected by him, O'Linn J granted the application and recused himself from hearing the case.

41 Per Lord Hope, Millar v Dickson 20021 LRC 457 (PC) para 64.

42 Wewaykum paras 63-66.

$43 R v$ Gough 1993 AC 646 (HL) 665. See also The Queen v Barnsley JJ 19602 QB 167 (CA). 
justices sit." Thirdly, the presence or absence of actual bias may not be relevant to the inquiry since the longstanding aphorism is that "it is not merely of some importance but is of fundamental importance that justice should not only be done, but should manifestly and undoubtedly be seen to be done." ${ }^{44}$ The Supreme Court then concluded:

\begin{abstract}
Of the three justifications for the objective standard of reasonable apprehension of bias, the last is the most demanding for the judicial system, because it countenances the possibility that justice might not be seen to be done, even where it is undoubtedly done - that is, it envisions the possibility that a decision-maker may be totally impartial in circumstances which nevertheless create a reasonable apprehension of bias, requiring his or her disqualification. But, even where the principle is understood in these terms, the criterion of disqualification still goes to the judge's state of mind, albeit viewed from the objective perspective of the reasonable person. The reasonable person is asked to imagine the decisionmaker's state of mind, under the circumstances. ${ }^{45}$
\end{abstract}

\title{
$4 \quad$ Presumption of impartiality
}

The courts approach the constitutional challenge of legislation by way of an interpretative restraint based on a presumption that the law made by the elected representatives of the people is constitutional until the particulars of the unconstitutionality are shown. In the same manner, they approach an allegation of apprehension of bias against superior court judges with the presumption of impartiality. This is the first hurdle to surmount in an attempt to show that a judge had conducted the proceeding in a way that raises an apprehension of bias. The courts take the view that given the nature of the judicial office and the oath of office of superior court judges, there is no presumption that such a highly dignified public functionary would discharge his/her important judicial office with favour, prejudice or partiality. On the other hand, the rationale for the presumption is founded on: (a) public confidence ${ }^{46}$ in the common law system, which is rooted in the fundamental

44 Per Lord Hewart CJ, R v Sussex JJ ex parte McCarthy 19241 KB 256259.

45 Wewaykum para 67.

46 That the courts jealously guard over anything that might impinge upon public confidence in the administration of justice is illustrated by the English Court of Appeal decision in Stansbury $v$ Datapulse 2004 IRLR 466 (CA) para 33. Gibson LJ (Latham LJ and Nourse J concurring) held that a hearing before an Employment Tribunal might be unfair where a lay member hearing the matter was unable to give the hearing his full attention through the consumption of alcohol or falling asleep. Further, that a hearing by a tribunal which included a member who had been drinking alcohol to the extent that he appeared to fall asleep and not to be concentrating on the case did not give the appearance of fair hearing to which every party was entitled. Public 
belief that those who engage in adjudication must always do so without bias or prejudice and must be perceived to do so; (b) impartiality is the fundamental qualification of a judge and the core attribute of the judiciary; it is the key to the common law judicial process and must be presumed on the part of a judge; ${ }^{47}$ (c) in view of the training and experience; the fact that they are persons of conscience and intellectual discipline; and capable of judging a particular controversy fairly on the basis of its own circumstances, ${ }^{48}$ appellate courts inquiring about apprehension of bias grant considerable deference to judges by the presumption of impartiality on the part of judges; and (d) this presumption carries "considerable weight" 49 since the law "will not suppose possibility of bias in a judge, who is already sworn to administer impartial justice, and whose authority greatly depends upon that presumption and idea." 50

Restating this ancient rule in $R v S(R D),{ }^{51}$ Cory $\mathrm{J}$ said:

Courts have rightly recognised that there is a presumption that judges will carry out their oath of office.... This is one of the reasons why the threshold for a successful allegation of perceived judicial bias is high. However, despite this high threshold, the presumption can be displaced with 'cogent evidence' that demonstrates that something the judge has done gives rise to a reasonable apprehension of bias. ${ }^{52}$

confidence in the administration of justice would be damaged were the court to take the view that such behaviour did not matter whereas the member's conduct was "wholly inappropriate" for any member of a tribunal.

47 See e.g. $R v S(R D) 19973$ SCR 484 para 106; Wewaykum paras 58 and 59. See also Canadian Judicial Council Ethical Principles 30.

48 US v Morgan 313 US 409 (1941) 421.

49 Per L'Heureux-Dube and McLachlin JJ, Rv S (RD) 19973 SCR 484 para 32.

50 Blackstone Commentaries on the Laws of England III 361.

$51 \quad R v S(R D) 19973$ SCR 484 para 34.

52 Such cogent evidence did not exist in Mugesera $v$ Canada (Minister of Citizenship and Immigration 2005254 DLR $\left(4^{\text {th }}\right) 193$ (SCC) paras 13-16. In an appeal against the order of the Federal Court of Appeal setting aside a deportation order against the respondent, it was alleged that the Minister, some of his Ministerial colleagues and a strong Jewish lobby had conspired to have the respondent and his family deported from Canada. Although Justice Abella, a recent appointee to the Supreme Court Bench, had of her own accord voluntarily recused herself from sitting in the matter because her husband was chair of the War Crimes Committee of the Canadian Jewish Congress, a party to the proceedings, the respondent had alleged that she was appointed to the Supreme Court to deliver judgment that will lead to his deportation. There was no evidence that any of the judges of the Supreme Court who heard the case had anything to do with the case prior to the court proceeding. Thus, no reasonable person would think that after recusal Abella J's mere presence as a member of the court would impair the ability of the other members to remain impartial. Without an iota of evidence to rebut the presumption of impartiality, it was held that it operated against the respondent whose motion was "flagrantly without basis in fact or in law." It constituted "an unqualified and abusive attack on the integrity of the Judges of this Court." The court further observed: "If there is a duty on the part of one member of our Court to recuse him or herself, it is an astounding proposition to suggest that the same duty 
The persistence of this presumption in Canadian law was recently reiterated by the Supreme Court in these words: "the presumption of impartiality carries considerable weight, and the law should not carelessly evoke the possibility of bias in a judge, whose authority depends upon that presumption." ${ }^{53}$ The effect of this presumption is that "while the requirement of judicial impartiality is a stringent one, the burden is on the party arguing for disqualification to establish that the circumstances justify a finding that the judge must be disqualified." 54

South African courts also apply the presumption that judicial officers are impartial in adjudicating disputes. ${ }^{55}$ Thus, in adopting the opinion expressed in $R v S(R D)$ as "entirely consistent with the approach of South African courts to applications for the recusal of a judicial officer," the Constitutional Court held in SARFU 2 that a presumption in favour of judges' impartiality must be taken into account in deciding whether or not a reasonable litigant would have entertained a reasonable apprehension that the judicial officer was or might be biased. ${ }^{56}$ The court emphasised the effect of the presumption to be that the person alleging must go further to prove. It must be recalled that the applicant in this case requested that about half of the Constitutional Court bench should be recused from sitting in appeal on his matter. It would appear, therefore, that the higher in the judicial hierarchy, the higher is the burden of proof of the apprehended bias against the judge, especially in a multi-judge panel.

In considering the numerous allegations based on the apprehension of bias in $S v$ Basson 2, ${ }^{57}$ the Constitutional Court held that the presumption in favour of the trial judge must apply. This means, first, that the court considering a claim of bias must take into account the presumption of impartiality. Secondly, in order to establish bias, a complainant would have to show that the remarks made by the trial judge were of

automatically attaches to the rest of the Court or compromises the integrity of the whole Court. To reach that conclusion would be to ascribe a singular fragility to the impartiality that a judge must necessarily show, and to the ability of judges to discharge the duties associated with impartiality in accordance with the traditions of our jurisprudence".

53 Wewaykum para 59.

54 Wewaykum para 59.

55 Eg S v Radebe 19731 SA 796 (A) 813F-G; $R v$ T 19532 SA 479 (A) 483C-D.

56 SARFU 2 para 41.

57 Basson 2 para 30. 
such a number and quality as to go beyond any suggestion of mere irritation by the judge caused by a long trial. It had to be shown that the trial judge's was a pattern of conduct sufficient to "dislodge the presumption of impartiality and replace it with reasonable apprehension of bias." ${ }^{58}$ In Bernert, the court stressed that both the person who apprehends bias and the apprehension itself must be reasonable. Thus, the two-fold emphasis serves to underscore the weight of the burden resting on a person alleging judicial bias or its appearance. ${ }^{59}$ This double-requirement of reasonableness also "highlights the fact that mere apprehensiveness on the part of a litigant that a judge will be biased - even a strongly and honestly felt anxiety - is not enough." The court must carefully scrutinise the apprehension to determine if it is, in all the circumstances, a reasonable one. ${ }^{60}$

\section{$5 \quad$ Test for establishing bias}

The current double reasonableness test, which commenced its journey in the Supreme Court of $\mathrm{Canada}^{61}$ and then travelled through the High Court of Australia, ${ }^{62}$

58 Basson 2 para 42. See also SACCAWU paras 13 and 14. Thus, in Stainbank para 45, it was held that there was no question that the judge was irritated by the conduct of the applicant's attorney given his disregard of the rules. But bearing in mind that the applicant was responsible for that, it was understandable that he might have formed a subjective impression that the judge was biased against him. Although Khampepe $\mathrm{J}$ found that this case came close to satisfying the reasonable apprehension test, she held that all factors considered, it fell short of dislodging the presumption of impartiality. Hence the case of bias failed.

59 SACCAWU para 15.

60 Bernert para 34; De Lacy para 70.

61 In Committee for Justice and Liberty v National Energy Board 197868 DLR (3d) 716735 de Granpré $\mathrm{J}$ laid down what has become the trademark of public adjudication in modern Canada when he stated that: "the apprehension of bias must be a reasonable one, held by reasonable and right minded persons, applying themselves to the question and obtaining thereon the required information. ... That test is 'what would an informed person, viewing the matter realistically and practically - and having thought the matter through - conclude.' Would he think that it is more likely than not that [the decision-maker], whether consciously or unconsciously, would not decide fairly?" See also Newfoundland Telephone 636; Reference re: Public Sector (The Provincial Court Judges case) 1997)150 DLR $\left(4^{\text {th }}\right) 577$ 630; R v S (RD) 19973 SCR 484 paras 11, 31 and 111; 1997118 CCC (3d) 353369 per McLaughlin J and L'Heureux-Dubé J, per Cory J 389-390; $R$ v Valente 198624 DLR $\left(4^{\text {th }}\right) 161$ 172; Baker v Canada (Minister of Citizenship and Immigration) 1999174 DLR $\left(4^{\text {th }}\right) 193$ 220-221; Therrien $v$ Minister of Justice 2001200 DLR 155 para 102; Miglin v Miglin 2003 SCC 24 (CanLII) para 26; Wewaykum paras 59-60; $R v$ Brown 2003 CanLII 52142 (Ont CA) para 37; Marchand (Litigation Guardian of) v Public General Hospital Society of Chatham 2000 CanLII 16946 (ONCA) (leave to appeal to SCC refused 2002 156 OAC 358); $R v$ Werner 2005 NWTCA 5 (CanLII) para 11; $R \vee$ Quinn 2006 BCCA 255 (CanLII) para 54.

62 In Livesey v NSW Bar Association 1983151 CLR 288 293-294, the previous "high probability" test was supplanted by the reasonable apprehension test, which was laid down by the High 
is so called because it translates into a two-stage requirement of reasonableness. It is a refinement of sorts of the formulation by the late Professor De Smith in his rationalisation of the real likelihood test as "based on the reasonable apprehensions of a reasonable man."63 There must be an apprehension of bias that must be reasonably entertained. That is the first stage. In the second stage, the apprehension must be one held by a reasonable person, someone who need not have interest in the outcome of the matter in court other than the general interest shared by the public in the fair administration of justice. The fulfilment of this general interest is mainly a pre-occupation with a fair administration of justice; a concern that justice is not only done but is manifestly and undoubtedly seen to be done.

In order to satisfy the requirement that an apprehension of bias must be reasonable in the circumstances, the reasonable, objective, informed and fair-minded person enters the fray. ${ }^{64}$ It follows that an application for the disqualification of a judge will not succeed if the applicant fails to demonstrate that the adjudicator in the circumstances might have departed or was in danger of departing from the standard of even-handed justice, or that there appeared the possibility that the judge might incline to one side or the other in the dispute. ${ }^{65}$ This requirement for anyone

Court as follows: "That principle is that a judge should not sit to hear a case if in all the circumstances the parties or the public might entertain a reasonable apprehension that he might not bring an impartial and unprejudiced mind to the resolution of the question involved in it." Applied in subsequent High Court cases: Vakauta v Kelly 1989167 CLR 568; Webb v The Queen 1994181 CLR 41; Johnson v Johnson 2000201 CLR 488; Ebner v Official Trustee in Bankruptcy 2000205 CLR 337; Re Minister for Immigration and Multicultural Affairs; Ex parte Epeabaka 2001206 CLR 128; Hot Holdings Pty Ltd v Creasy 2002210 CLR 438. See also Australian National Industries Ltd v Spedley Securities Ltd 199226 NSWLR 411; Gas and Fuel Corporation Superannuation Fund v Saunders 199452 FCR 48. In McGovern v Ku-Ring-Gai Council 2009251 ALR 558, the Court of Appeal of New South Wales, dealing with apprehension of bias on the ground of prejudgment in the context of a non-judicial multi-member elected decision-making body not subject to the stringent requirements of a court of law, held that the test for apprehension of bias by prejudgment was if an independent observer might reasonably apprehend that the decision-maker might not be open to persuasion and that in this context, there was no requirement that each of the decision-makers kept an "open mind" until every decision-maker was prepared to make a decision. The trial judge had asked the incorrect question relating to the test by asking if the decision-maker would, rather than might, not be impartial, although he came to the conclusion that would have arisen from asking the correct question.

63 De Smith Judicial Review 230.

64 Sager v Smith 20013 SA 1004 (SCA); S v Roberts 19994 SA 915 (SCA). See also the judgment of Leon JP in the Swazi Court of Appeal in Minister of Justice and Constitutional Affairs $v$ Stanley Wilfred Sapire; In Re Stanley Wilfred Sapire 2002 (Unreported) Civ Appeal No. 49/2001 (Re Sapire).

65 The applicable test in federal law in the United States is similar to the test under discussion. For instance, the United States Supreme Court held in Likety v United States 510 US 540 (1994) 564 that disqualification is required "if an objective observer would entertain reasonable questions 
occupying the judicial office applies equally in England, ${ }^{66}$ Lesotho, ${ }^{67}$ Swaziland ${ }^{68}$ and the European Human Rights regime. ${ }^{69}$

Like the Australian High Court in Livesey, and the Canadian Supreme Court in $R v S$ $(R D)$, the Constitutional Court of South Africa opted for the "reasonable apprehension" test because of "the inappropriate connotations which might flow from the use of the word 'suspicion' in this context." ${ }^{70}$ As formulated, the test is: "whether a reasonable, objective and informed person would on the correct facts reasonably apprehend that the judge has not or will not bring an impartial mind to bear on the adjudication of the case, that is, a mind open to persuasion by the evidence and submissions of counsel." ${ }^{71}$ Unfortunately, however, in reading recent judgments of

about the judge's impartiality. If a judge's attitude or state of mind leads a detached observer to conclude that a fair and impartial hearing is unlikely, the judge must be disqualified." See generally Flamm Judicial Disqualification.

66 In England, the journey started with the modifications of the then existing test by the Court of Appeal in Re Medicaments and Related Classes of Goods (No 2) 20001 WLR 700 para 85; the overruling of the "real danger" test by the House of Lords in Potter v Magill 20022 AC 357; and the unanimous endorsement of the adjusted test in Lawal v Northern Spirit Ltd 2003 IRLR 538 $(\mathrm{HL})$ para 14 by the House of Lords. See further Meerabux v Attorney General of Belize 20052 AC 513 (PC); Gilles $v$ Secretary of State for Works and Pensions 2006 UKHL 2; $R v$ Abdroikov 20081 All ER 315 (HL); AWG Group Ltd v Morrison 2006 EWCA Civ 6; R v Khan 20083 All ER $502(\mathrm{CA})$.

67 Sole v Cullinan 20038 BCLR 935 (Les CA); Sekoati v President of the Court Martial 20017 BCLR 750 (LAC).

68 Re Sapire; Law Society of Swaziland v Swaziland Government Civil Case No. 743/2003 (17 April 2003); Lawyers for Human Rights v Attorney General of Swaziland 2001 (Unreported) Appeal Case No. 34/2001; Dumisa Mbusi Dlamini v Swaziland Electricity Board Appeals Nos. 15 and 18 of 1999.

69 In Findlay v United Kingdom 199724 EHRR 221 para 73, it was stated that: "[i]n order to establish whether a tribunal can be considered as 'independent', regard must be had inter alia to the manner of appointment of its members and their term of office, the existence of guarantees against outside pressures and the question whether the body presents an appearance of independence. As to the question of 'impartiality', there are two aspects to this requirement. First, the tribunal must be subjectively free of personal prejudice or bias. Secondly, it must also be impartial from an objective viewpoint, that is, it must offer sufficient guarantees to exclude any legitimate doubt in this respect." Affirming this approach in McGonnell v UK 20008 BHRC 56 para 57, the European Court of Human Rights held that the issue was whether the Bailiff of Guernsey had the required "appearance of independence" or the required "objective impartiality" in circumstances where the Bailiff functions in judicial as well as non-judicial capacities. The Bailiff while acting as Deputy Bailiff in the present matter had presided over the Legislative Assembly deliberations over the plaintiff's planning application. Subsequently, he presided over the applicant's planning appeal to the Royal Court. The court held that these circumstances were capable of casting doubt on his impartiality when he subsequently determined, as the sole judge of the law in the applicant's appeal. The applicant was therefore entitled to the legitimate view that the Bailiff might have been influenced by his prior participation in the Assembly's decision on the planning application. "That doubt in itself, however slight its justification, is sufficient to vitiate the impartiality of the Royal Court, and it is therefore unnecessary for the court to look into other aspects of the complaint."

70 SARFU 2 para 38.

71 SARFU 2 para 48; SACCAWU paras 11-17. 


\section{the Supreme Court of Appeal of South Africa, one discerns a jumbled approach}

whereby the jettisoned test of reasonable suspicion is muddled with the current and prevailing test. $^{72}$

In effect, notwithstanding the fact that the reasonable apprehension test has been systematically applied, ${ }^{73}$ quite recently, ${ }^{74}$ when the Supreme Court of Appeal was

72 Similarly, the Lesotho High Court sitting as a Constitutional Court wittingly or unwittingly deviated from the double-reasonableness test earlier endorsed by the Court of Appeal judgment (Sole $v$ Cullinan 20038 BCLR 935 (Les CA)). The argument in the controversial "Mercedes Benz gift case" was that most of the Judges of the High Court including the three sitting to hear the matter in Molapo v Ntsekhe Civ/P/2/2007 (8 August 2007), an election petition, should recuse themselves as they benefitted from the scheme whereby they were enabled to purchase Mercedes Benz cars for paltry amounts. It was alleged that, as beneficiaries of the said scheme, the three Judges could not reasonably be perceived as impartial arbiters in a disputed election which may have an influence on the balance of power in Parliament. The question before the court was whether the Judges of the High Court having been listed in the relevant legal instrument as beneficiaries to the Imperial Scheme thereby being able to purchase the said motor vehicles at predetermined prices, there was a real likelihood that the Judges of the panel might be inclined to be prejudiced in favour of the Lesotho Congress for Democracy, the ruling majority party in the election petition involving the applicants and the respondents. Even after referring to the South African Supreme Court of Appeal's emphasis on the double reasonableness test as captured in Sole $v$ Cullinan by Gauntlett JA, Peete $J$ still fell back on the real likelihood test. At another stage, the Judge reverted to the double reasonableness test relying on BTR Industries South Africa (Pty) Ltd v Metal and Allied Workers Union 19923 SA 673 (A) $690 \mathrm{~A}-695 \mathrm{C}$, which was the precursor to the current test formulated by the Constitutional Court of South Africa in SARFU 2. The difference in the two approaches is that in BTR Industries, no distinction was drawn between real likelihood, reasonable suspicion or reasonable apprehension of bias; all three expressions appeared to have been used interchangeably somewhat akin to the approach of Lord Brown-Wilkinson in Pinochet [No 2] 19991 All ER 577 586b. Finally, Peete $\mathrm{J}$ held that although some of the Judges had purchased Mercedes Benz vehicles, an act which was not shown to have been illegal or corrupt, this could not have created in the mind of a reasonable right-thinking person a reasonable apprehension that the said Judges would likely be biased in favour of the ruling party merely because it was apprehended that the Judges had an interest in the outcome of the election petition. No right-thinking Judge contrary to his/her solemn Oath of Office would be inclined to bend his or her impartiality in favour of any party (including the majority party) merely because Mercedes Benz Kompressor cars had been allocated to them for their use and for their ultimate purchase at whatever terms or price.

73 Take and Save Trading CC 20044 SA 1 (SCA); Van Rooyen v The State (General Council of the Bar of South Africa Intervening) 20025 SA 246 (CC); S v Shackell 20014 SA 1 (CC); KwaZulu Transport (Pty) Ltd v Mnguni 200122 ILJ 1646 (LC); Natal Rugby Union v Gould 19991 SA 432 (SCA); Financial Services Board v Pepkor Pension Fund 19991 SA 167 (C).

74 Indeed, Wallis J held in Ndlovu v Minister of Home Affairs 20112 SA 621 paras 20, 35 and 38 that the law with regard to applications for recusal was settled in the trilogy of Constitutional Court cases: SARFU 2 paras 35-48; SACCAWU paras 11-17; and Bernert paras 28-37. The learned Judge proceeded to apply the double-reasonableness test embedded in those judgments in determining the application for his recusal for apprehension of bias arising from the critical views he expressed in a public lecture relating to a system of contingency fees which he argued required safeguards to prevent its being exploited by legal practitioners who might see in it an opportunity to enrich themselves. The applicant's ground for recusal was that the judge held a fixed view - a prejudgment - on the costs order which the applicant sought. It was held that no reasonable, objective reader would conclude, after reading the judge's article and with knowledge that the area of costs was one in which there was enormous body of well-established authority setting out principles that bind a judge, that in any case involving contingency fees that 
faced with the issue of structural bias in Islamic Unity Convention $v$ Minister of Telecommunications and Others, ${ }^{75}$ it appeared to have lumped it together with the "reasonable suspicion of bias" of BTR Industries South Africa (Pty) Ltd and Others v Metal and Allied Workers Union and Another ${ }^{76}$ vintage. Again, although the test for determining bias or apprehension of it was not in issue in $S v K_{\text {Khoza }}^{77}$ but whether the conduct of the trial was riddled with procedural as well as substantive irregularities, Mhlantla JA referred to the "suspicion of bias" in considering whether or not a trial was vitiated by bias on the part of the judge. In contrast to the foregoing is the approach of Mpati $\mathrm{P}$ in Ndimeni $v$ Meeg Bank Ltd (Bank of Transkei). ${ }^{78}$ The court was called upon to decide whether or not an Acting Judge should have recused himself from hearing the labour dispute because "close members of [his] family" had some commercial relationship with the respondent. The President held that the facts "satisfy the requirements of the 'reasonable apprehension of bias' test." ${ }^{79}$ There was no mention of the other cases or indeed of any other test, discarded or prevailing.

As already noted, the reasonable "suspicion of bias" test was discarded in SARFU $2^{80}$ because of the inappropriateness of its connotations. Clearly, the approach of the Supreme Court of Appeal could have been rationalised on the basis that the application came to court by way of the judicial review of administrative action under section 6(2)(a)(iii) of the Promotion of Administrative Justice Act of $2000 .^{81}$ This subsection recognises bias or the reasonable suspicion of bias as a ground of the judicial review of administrative action. But the court made no attempt to explain whether it applied the test in Islamic Unity Convention because it was reviewing a decision on PAJA ground, or if the SARFU 2 test did not apply to the matter. It must be admitted that section 6(2)(a)(iii) introduced in its own right elements of confusion in a subject where judges and academics alike agree that it is a matter of

came before the judge, he would disregard the established principles and make a finding on the costs adverse to the party whose lawyers were employed on a contingency-fee basis.

75 Islamic Unity Convention v Minister of Communications 20083 SA 383 (SCA) para 40.

76 BTR Industries South Africa (Pty) Ltd v Metal and Allied Workers Union 19923 SA 673 (A).

77 S v Khoza 20102 SACR 207 (SCA) para 61.

78 Ndimeni v Meeg Bank Ltd (Bank of Transkei) 20111 SA 560 (SCA).

79 Ndimeni v Meeg Bank Ltd (Bank of Transkei) 20111 SA 560 (SCA) para 23.

80 SARFU 2 para 38.

81 Promotion of Administrative Justice Act 3 of 2000. 
semantics $^{82}$ and as Baxter put it, there is "a welter of unintentional terminological vacillation" in this field. ${ }^{83}$ But does it follow, as Hoexter suggests, that the Constitutional Court's preference for the "reasonable apprehension" test is confined to "cases relating to the recusal of judges"? ${ }^{84}$ Taking a second look at the logic of that reasoning, does it then mean that there are two tests: (a) "reasonable suspicion" for the application for judicial review under section 6(2)(a)(iii); and (b) "reasonable apprehension" where a recusal application is made? In the absence of any further explanation as to why this should be the case, it would appear that the prevailing test in any of the two circumstances postulated remains the acceptable double reasonableness test described in this article. If an applicant alleges bias or reasonable suspicion of bias in accordance with section 6(2)(a)(iii), that is the cause of action and the test in determining if the allegation is proved is the reasonable apprehension of a reasonable person test.

Upon all of these, the Constitutional Court in Basson $2^{85}$ itself spoke of there being two different approaches to the determination of the appearance of bias. The first focused on whether or not there was a real likelihood of bias, while the second concerned the existence or otherwise of a reasonable apprehension of bias. It was not necessary for a litigant who complained of bias to establish that there was a real likelihood of bias; a real apprehension of bias was sufficient. In this sense, a real likelihood of bias assumes the role of actual bias and, if this is so, it falls off as a test and turns into a question of fact. In these circumstances, clarifications would be desirable from the same Constitutional Court, the highest judicial authority on constitutional jurisdiction in South Africa, as to whether this development is a slip, a misconception, or the outcome of a deliberately intention to return to the status quo ante.

Now, did the Constitutional Court take the opportunity of addressing the problem in Bernert and/or De Lacy? ${ }^{86}$ The answer to this question is not clear-cut. Depending on how one looks at the matter, it could be argued that by not referring to the current

82 See e.g. Devenish, Govender and Hulme Administrative Law and Justice 334.

83 Baxter Administrative Law 558.

84 Hoexter Administrative Law 407.

85 Basson 2 para 29.

86 De Lacy para 70. 
approach of the Supreme Court of Appeal, the Constitutional Court more or less turned a blind eye to that development as well as to the confusion it created in Basson 2. In both Bernert and De Lacy the court simply proceeded to restate the double reasonableness test which has dominated South African adjudication since SARFU 2. It could be argued in the alternative that the issue of reformulating the appropriate or existing test was not before the court and that its reference to the double-reasonableness test was in the normal course of disposing of the questions for determination in both cases. Remarkably, the court dwelt extensively on the double-reasonableness test in Bernert ${ }^{87}$ in dealing with the question: when will shareholding or other financial interest in a litigant company by a judicial officer give rise to a reasonable apprehension of bias? And further, when does ownership of shares by a judicial officer in a litigant company give rise to a reasonable apprehension of bias? In his judgment, Ngcobo CJ left no one in doubt that the answer lies in the double-reasonableness test enunciated and applied in this jurisdiction. With the concurrence of the entire bench he held that:

Inevitably, a reasonable, objective and informed person would reasonably apprehend that a judicial officer who has a direct financial interest in the outcome of proceedings would not bring an impartial mind to bear on the adjudication of the case. Although a judicial officer may have a pecuniary interest in the form of shares or other financial interest in a company that is a party to the proceedings before him or her that does not necessarily mean that the judicial officer has a financial interest in the outcome of those proceedings. In many cases in which a company is a party to the litigation, the outcome of the proceedings may have no capacity to affect the value of the shares held by the judicial officer or his or her ownership of those shares. A reasonably informed litigant, therefore, would not reasonably apprehend that, simply because a judicial officer owns shares in a litigant company, the judicial officer would not bring an impartial mind to bear in adjudicating the case. But at the same time, it cannot be assumed that proceedings in which a company is a party will not affect the shares held by the judicial officer in that company or his or her interest in those shares. ${ }^{88}$

Since the foregoing pronouncements were no mere dicta but an essential part of the ratio, one may argue that it could reasonably be inferred that in reiterating and reinvigorating the double-reasonableness test in Bernert and De Lacy, the Constitutional Court could be said to have set the record straight. ${ }^{89}$

87 Bernert paras 45-66.

88 Bernert para 46.

89 No mention was made of the problem in the Constitutional Court judgment in Stainbank para 35. The court merely and briefly reiterated the test. 


\section{De Lacy in context}

When the facts in this case are assessed with regard to the presumption of judicial impartiality and the double requirement of reasonableness, could a fair-minded, reasonable observer have reasonably apprehended that the court, or the presiding judge, or both were biased in rendering a judgment that reversed the award made by the trial judge? Given the nature of the allegations the appellants made against the judges who rendered the judgment whereby a whopping R60m evaporated before their very eyes, neither the appellants nor their counsel could have been described as being anything like objective bystanders. The court had no doubt that the prevailing jurisprudence in South Africa is that a judicial officer who sits on a case in which there exists a reasonable apprehension that he or she might be biased acts in a manner that is inconsistent with the Constitution. The judicial system requires that courts must not only be impartial and independent; they must also be seen to be so. Thus an apprehension of bias, if reasonable, would entitle an aggrieved litigant to have the adverse decision set aside. ${ }^{90}$

Bias claims are not only "fact-driven;"11 they are "highly fact-specific."92 A claim based on the adjudicative partiality of a court must therefore be based on facts ${ }^{93}$

90 De Lacy para 68; Bernert para 28; SARFU 2 para 35.

91 Peart $v$ Peel Police 2006 CanLII 37566 (Ont CA) para 40. The recent New Zealand case of Smith $v$ Attorney General 2010 NZCA 258 (CA) paras 14, 19 and 22-25 is a good illustration. In it the appellant, a prisoner, sought to review his classification as a maximum security prisoner as unlawful due to some alleged breaches of the rules of natural justice but got embroiled in several unsubstantiated recusal applications. Before the Court of Appeal, the appellant made a recusal application of all three judges or at least some of them, relying first on the fact that the panel was not chosen by lot, a system not normally used in that court. The court dismissed this argument since a lottery was not what was required by law. The second was that the wife of one of the Judges was a member of the parole board. This matter was brought to the attention of the panel prior to the hearing by the judge in question. She had participated in a relatively recent review of the appellant's case but had nothing to do with the reviews before court, the events of which happened a long time previously. The panel discussed the matter collectively and took the view that the matter should be drawn to the attention of counsel, who confirmed that he had no concerns. The appellant now argued that the panel should not have met to discuss the issue prior to the hearing. This argument, like the first, overlooked the practice in judicial quarters where, in principle, discussion between judges is a good thing from the beginning to the end of a case. See also Australian Institute of Judicial Administration Guide to Judicial Conduct 15-16; Paterson Law Lords 91. The third ground of recusal was that Arnold J was Solicitor General when the appellant's appeal was dealt with in 2003. Here, again, there was no evidence that Arnold $\mathrm{J}$ had had any involvement in that appeal. Finally, it was contended that the panel was not independent because of some entitlement matters. It was alleged that when Arnold $\mathrm{J}$ was Solicitor General, he had written a report as to the unequal superannuation entitlements of pre- 
substantial enough to satisfy the requirements of the fair-minded reasonable observer. In De Lacy the applicants alleged only that the Supreme Court of Appeal committed 114 factual errors which were not borne out by the record. They based their case on the formulations in Basson and Bernert, where it was held that a mistake on the facts will give rise to a reasonable apprehension of bias only if it was so unreasonable on the record that it was inexplicable except on the basis of bias. The court held in both cases that a mistake on the facts, even if it were so shown, would not ordinarily be sufficient on its own to justify a reasonable apprehension of bias. A litigant who relies on bias based on incorrect factual findings indeed carries the onus of establishing the partiality, and this, indeed, is a formidable onus to discharge. For that to happen, an applicant must, in the first instance, show that the factual findings were erroneous on the appeal record. This is a threshold requirement. If it is not met "the question of unreasonableness will not arise, and the litigant fails at the first hurdle." ${ }^{94}$ However, if a mistake on the facts is shown it will justify a reasonable apprehension of bias only if the error relates to a material fact and it is so unreasonable that it is inexplicable except on the grounds of bias. ${ }^{95}$

Delivering a judgment unanimously endorsed by all members of the Constitutional Court, Moseneke DCJ emphasised three important requirements where an applicant relies on a reasonable apprehension of bias based on incorrect factual findings. They must show that: "the impugned findings are not supported by the record; the findings are not mere misdirections but are errors that are so unreasonable that they are inexplicable except on the basis of a reasonable apprehension of bias; and, the factual findings complained of are material to the outcome of the underlying claim. It is self-evident that if an error complained of is immaterial or unrelated to the outcome of the case, then it can hardly be said to induce a reasonable apprehension of bias". 96

and post-1992 judges. The bearing this might have had on the judicial independence of the court was unclear. Hence it was, like the other allegations, dismissed by the Court of Appeal.

92 Wewaykum paras 76-78; Lesiczka v Sahota 2007 BCSC 479 (CanLII) para 13.

93 Christian t/a Hope Financial Services v Chairman, Financial Services Board (1) 20091 NLR 22 ( $\mathrm{HCNm})$.

94 Bernert paras 102-103; Basson 2 para 70.

95 De Lacy paras 71-72.

96 De Lacy para 76. 
It was held, nonetheless, that the Supreme Court of Appeal committed no factual error. It was obvious that in the absence of direct evidence of dishonesty and corrupt manipulation the two courts drew entirely different inferences. ${ }^{97}$ Thus, having examined the big ticket items the applicants put up as examples of findings that diverge from the record, it was overwhelmingly clear that the applicants failed to show that the judgment complained of contained any material irregularity reasonably capable of inducing a reasonable apprehension of bias. There was also nothing in the findings of that court that could ever justify the "baseless and scurrilous accusations of a deliberate distortion of facts and actual bias on the part of the panel of five judges of an appellate court." ${ }^{98}$ Accordingly, the bias claim had no prospects of success whatsoever.

The foregoing discussion would have brought home at least three hard facts which applicants for the apprehension of bias often lose sight of. The first is the admonitions of Mason $\mathrm{J}$ whereby he made it clearly" that the fact that the ground of disqualification is a reasonable apprehension that the judicial officer will not decide the case impartially or without prejudice does not mean that he will decide the case adversely to one party. ${ }^{99}$ The second is the statement that allegations are easier made than proved applies more appropriately to the present case than in any other. The third is that in a case such as De Lacy, there is an element of truth to the saying that a "charge of actual bias is tantamount to a plea of fraud." 100 Not only is cogent evidence required to prove its existence, but it must be "clearly pleaded and particularised" in court proceedings. ${ }^{101}$ This means that the burden of proof of actual bias, especially where it is alleged to have been deliberate, is as heavy as the burden of proof of fraud, bad faith or misfeasance in public office. The appellants in De Lacy merely alleged but could not prove any of their allegations against the Supreme Court of Appeal or the presiding Judge. De Lacy clearly falls within the category of cases described by Wade and Forsyth as "fanciful allegations of bias."102

97 De Lacy para 83.

98 De Lacy para 113.

99 Re JRL; Ex parte CJL 1986161 CLR 342 352. See also per Brennan, Gaudron and McHugh JJ, Re Polites; Ex parte Hoyts Corporation Pty Ltd 1991173 CLR 78 86; Locabail 480.

100 Forbes Justice in Tribunals para 15.7.

101 Forbes Justice in Tribunals para 15.7.

102 Wade and Forsyth Administrative Law 385. 


\section{Conclusion}

The cases discussed in this article are diverse in their approach to the subject of bias but, as the analysis has shown, they indicate some pattern of settled principles which complainants must contend with in order to convince a court of the genuineness of their allegations. The first of those principles is the presumption of impartiality, which often works in favour of the court. Failure to rebut this presumption makes the complainant's task a lot harder. The second is meeting the test of the fair-minded observer. This principle applies in tandem with the third, which is the doublereasonableness test. Undoubtedly, these two principles combine to remove the consideration of the issue of bias or the apprehension of bias from the subjective threshold into the more stringent objective standard category. As already shown, the applicants in De Lacy failed all three of these tests. And as the Constitutional Court held in Bernert, the presumption of impartiality and the double-requirement of reasonableness underscore the formidable nature of the burden resting upon the litigant who alleges bias or its apprehension. The idea is not to permit a disgruntled litigant to successfully complain of bias simply because the judicial officer has ruled against him or her. Nor should litigants be encouraged to believe that by seeking the disqualification of a judicial officer they will have their case heard by another judicial officer who is likely to decide the case in their favour. ${ }^{103}$ We hasten to conclude that no better illustration of the foregoing than De Lacy has graced the law reports in modern times.

103 Bernert para 35. See also The Citizen 1978 (Pty) Ltd v McBride 2011 ZACC 11 (8 April 2011) para 69. 


\section{Bibliography}

Australian Institute of Judicial Administration Guide to Judicial Conduct

Australian Institute of Judicial Administration Guide to Judicial Conduct $2^{\text {nd }}$ ed (AIJA Carlton 2007)

Baxter Administrative Law

Baxter L Administrative Law (Juta Cape Town 1984)

Blackstone Commentaries on the Laws of England III

Blackstone W Commentaries on the Laws of England III (Oxford Clarendon 1788)

Burns and Beukes Administrative Law

Burns $Y$ and Beukes M Administrative Law Under the 1996 Constitution $3^{\text {rd }}$ ed (LexisNexis Butterworths 2007)

Canadian Judicial Council Ethical Principles

Canadian Judicial Council Ethical Principles for Judges (Canadian Judicial Council Ottawa 1998)

De Smith Judicial Review

De Smith SA Judicial Review of Administrative Action $3^{\text {rd }}$ ed (Stevens London 1973)

Devenish 2000 TSAR

Devenish G "Disqualifying bias: The second principle of natural justice - the rule against partiality or bias (nemo judex in propria causa)" 2000 TSAR 397$495 ?$

Devenish, Govender and Hulme Administrative Law and Justice

Devenish GE, Govender K and Hulme DH Administrative Law and Justice in South Africa (Butterworths Durban 2001) 
Flamm Judicial Disqualification

Flamm RE Judicial Disqualification: Recusal and Disqualification of Judges (Little Brown Boston MA 1996)

Forbes Justice in Tribunals

Forbes JRS Justice in Tribunals $3^{\text {rd }}$ ed (Federation Press Annandale 2010)

Hoexter Administrative Law

Hoexter C Administrative Law in South Africa (Juta Cape Town 2007)

Okpaluba 2010 Lesotho Law Journal

Okpaluba C "Fraud, bad faith and misfeasance in public office: GORE in comparative perspective" 2010 Lesotho Law Journal 1-66

Okpaluba Right to a Fair Hearing

Okpaluba C The Right to a Fair Hearing in Nigeria $2^{\text {nd }}$ ed (Shelter International Lagos 1990)

Okpaluba and Osode Government Liability

Okpaluba C and Osode PC Government Liability: South Africa and the Commonwealth (Juta Cape Town 2010)

Paterson Law Lords

Paterson A The Law Lords (University of Toronto Press Toronto 1982)

Stevens 1999 Oxford Journal of Legal Studies

Stevens R "A loss of innocence? Judicial independence and the separation of powers" 1999 Oxford Journal of Legal Studies 365-402

Wade and Forsyth Administrative Law

Wade W and Forsyth CF Administrative Law $10^{\text {th }}$ ed (Oxford University Press Oxford 2009) 


\section{Register of legislation}

Promotion of Administrative Justice Act 3 of 2000

\section{Register of cases}

\section{Australia and New Zealand}

Australian National Industries Ltd v Spedley Securities Ltd 199226 NSWLR 411

Concrete Pty Ltd v Parramatta Design and Development Pty Ltd 2006231 ALR 663

Ebner v Official Trustee in Bankruptcy 2000205 CLR 337

EH Cochrane Ltd v Ministry of Transport 19871 NZLR 146 (CA)

Gas and Fuel Corporation Superannuation Fund v Saunders 199452 FCR 48

Hot Holdings Pty Ltd v Creasy 2002210 CLR 438

Johnson $v$ Johnson 2000201 CLR 488

Livesey v NSW Bar Association 1983151 CLR 288

McGovern v Ku-Ring-Gai Council 2009251 ALR 558

McGuirk v University of New South Wales 2010 NSWADTAP 66

Re JRL; Ex parte CJL 1986161 CLR 342

Re Minister for Immigration and Multicultural Affairs; Ex parte Epeabaka 2001206 CLR 128

Re Polites; Ex parte Hoyts Corporation Pty Ltd 1991173 CLR 78

Smith v Attorney General 2010 NZCA 258 (CA)

Stollery v Greyhound Racing Control Board 1972128 CLR 509

Vakuata v Kelly 1989167 CLR 568 (HCA)

Webb v The Queen 1994181 CLR 41

\section{Canada}

Baker v Canada (Minister of Citizenship and Immigration) 1999174 DLR $\left(4^{\text {th }}\right) 193$

Committee for Justice and Liberty v National Energy Board 197868 DLR (3d)

Committee for Justice and Liberty $v$ National Energy Board 19781 SCR 369 (SCC)

CUPE v Ontario (Minister of Labour) 2003226 DLR (4th) 193

Lesiczka v Sahota 2007 BCSC 479 (CanLII)

Marchand (Litigation Guardian of) $v$ Public General Hospital Society of Chatham 2000 CanLII 16946 (ONCA)

Miglin v Miglin 2003 SCC 24 (CanLII) 
Mugesera v Canada (Minister of Citizenship and Immigration) 2005254 DLR $\left(4^{\text {th }}\right)$ 193

Newfoundland Telephone Co v Board of Commissioners of Public Utilities 199289 DLR $\left(4^{\text {th }}\right) 289$ (Newfoundland Telephone)

Newfoundland Telephone Co $v$ Newfoundland (Board of Commissioners of Public Utilities) 19921 SCR 623

PCL Constructors Canada Inc v IABSORIW Local No 972008 CanLII 39763 (BCLRB)

Peart v Peel Police 2006 CanLII 37566 (Ont CA)

$R v$ Brown 2003 CanLII 52142 (Ont CA)

$R v(D S) 1997151 \operatorname{DLR}\left(4^{\text {th }}\right) 193$

$R v$ Quinn 2006 BCCA 255 (CanLII)

$R v S(R D) 19973 \mathrm{SCR} 484 ; 1997118$ CCC (3d) 353

$R v$ Valente $198624 \operatorname{DLR}\left(4^{\text {th }}\right) 161$

$R v$ Werner 2005 NWTCA 5 (CanLII)

Reference re: Public Sector (The Provincial Court Judges case) 1997150 DLR $\left(4^{\text {th }}\right)$ 577

Taku River Tlingit First Nation v Ringstad 2002211 DLR 89 (BCCA)

Therrien v Minister of Justice 2001200 DLR 1

Ultracuts Franchises Inc v Wal-Mart Canada Corp 2005 MBQB 222 (CanLII)

Wewaykum Indian Band v Canada 2003231 DLR $\left(4^{\text {th }}\right) 1$ (Wewaykum)

\section{European Court of Human Rights}

Findlay v United Kingdom 199724 EHRR 221

\section{South Africa and neighbouring countries}

Bam-Mugwanya $v$ Minister of Finance and Provincial Expenditure, Eastern Cape 20014 SA 120 (Ck)

Barnard $v$ Jockey Club of SA 19842 SA 35 (W)

Bernert v ABSA Bank Ltd 20113 SA 92 (CC) (Bernert)

BTR Industries South Africa (Pty) Ltd v Metal and Allied Workers Union 19923 SA $673(\mathrm{~A})$

Christian t/a Hope Financial Services v Chairman, Financial Services Board (1) 2009 $1 \mathrm{NLR} 22(\mathrm{HCNm})$ 
Commissioner, Competition Commission v General Council of the Bar of South Africa 20026 SA 606 (SCA)

De Lacy v South African Post Office 2011 ZACC 17 (24 May 2011) (De Lacy)

Derby-Lewis $v$ Chairman, Amnesty Committee of the Truth and Reconciliation Commission 20013 SA 1033 (C)

Dumisa Mbusi Dlamini $v$ Swaziland Electricity Board Appeals Nos. 15 and 18 of 1999

Financial Services Board v Pepkor Pension Fund 19991 SA 167 (C)

FS $v$ JJ 20113 SA 126 (SCA)

Islamic Unity Convention v Minister of Communications 20083 SA 383 (SCA)

KwaZulu Transport (Pty) Ltd v Mnguni 200122 ILJ 1646 (LC)

Law Society of Swaziland v Swaziland Government Civil Case No. 743/2003 (17 April 2003)

Lawyers for Human Rights $v$ Attorney General of Swaziland 2001 (Unreported) Appeal Case No. 34/2001

Liebenberg v Brakpan Liquor Licensing Board 1944 WLD 52

Mafongosi v United Democratic Movement 20025 SA 567 (Tk)

Minister of Finance $v$ Gore 20071 SA 111 (SCA)

Minister of Justice and Constitutional Affairs v Stanley Wilfred Sapire; In Re Stanley

Wilfred Sapire 2002 (Unreported) Civ Appeal No. 49/2001 (Re Sapire)

Molapo v Ntsekhe Civ/P/2/2007 (8 August 2007)

Natal Rugby Union v Gould 19991 SA 432 (SCA)

Ndimeni v Meeg Bank Ltd (Bank of Transkei) 20111 SA 560 (SCA)

Ndlovu v Minister of Home Affairs 20112 SA 621

President of the Republic of South Africa $v$ South African Rugby Football Union 1999 4 SA 147 (CC) (SARFU 2)

$R \vee T 19532$ SA $479(\mathrm{~A})$

Rose $v$ Johannesburg Local Road Transportation Board 19474 SA 272 (W)

$S$ v Bam 19724 SA 41 (E)

$S$ v Basson 20051 SA 171 (CC) (Basson 1)

$S$ v Basson 200512 BCLR 1192 (CC) (Basson 2)

$S v$ Boesak 20011 SA 912 (CC)

$S v$ Dawid 19911 SACR $375(\mathrm{Nm})$

$S$ v Khoza 20102 SACR 207 (SCA) 
$S v$ Marais 20111 SA 502 (CC)

$S v$ Radebe 19731 SA 796 (A)

$S v$ Roberts 19994 SA 915 (SCA)

$S$ v Shackell 20014 SA 1 (CC)

SACCAWU $v$ Irvin and Johnson Ltd 20003 SA 705 (CC) (SACCAWU)

Sager $v$ Smith 20013 SA 1004 (SCA)

Sekoati v President of the Court Martial 20017 BCLR 750 (LAC)

Sole $v$ Cullinan 20038 BCLR 935 (Les CA)

South African Post Office $v$ De Lacy 20095 SA 255 (SCA)

Stainbank $v$ South African Apartheid Museum at Freedom Park 2011 ZACC 20 (9 June 2011) (Stainbank)

Steenkamp v Provincial Tender Board, Eastern Cape 20063 SA 151 (SCA)

Steenkamp v Provincial Tender Board, Eastern Cape 20073 SA 121 (CC)

Take and Save Trading CC v Standard Bank of SA Ltd 20044 SA 1 (SCA)

The Citizen 1978 (Pty) Ltd v McBride 2011 ZACC 11 (8 April 2011)

Turner v Jockey Club of SA 1974 3 SA 644 (A)

Van Rooyen $v$ The State (General Council of the Bar of South Africa Intervening) 20025 SA 246 (CC)

\section{United Kingdom}

AWG Group Ltd v Morrison 2006 EWCA Civ 6

Davidson v Scottish Ministers 2004 UKHL 34

Dimes v Grand Junction Canal Co 18523 HL Cas 759

Gilles $v$ Secretary of State for Works and Pensions 2006 UKHL 2

In re Medicaments and Related Classes of Goods (No 2) 20011 WLR 700 (CA)

Lawal v Northern Spirit Ltd 2003 IRLR 538 (HL)

Locabail (UK) Ltd v Bayfield Properties Ltd 2000 QB 451 (Locabail)

McGonnell v UK 20008 BHRC 56

Meerabux v Attorney General of Belize 20052 AC 513 (PC)

Metropolitan Properties Co (FGC) Ltd v Lannon 19691 QB 577

Millar v Dickson 20021 LRC 457 (PC)

Pinochet [No 2] 19991 All ER 577

Potter v Magill 20022 AC 357

$R v$ Abdroikov 20081 All ER 315 (HL) 
$R v$ Bow Street Magistrate; Ex parte Pinochet [No 2] 20001 AC 119 (Pinochet [No 2])

$R v$ Gough 1993 AC $646(\mathrm{HL})$

$R v$ Khan 20083 All ER 502 (CA)

$R v$ Sussex JJ ex parte McCarthy $19241 \mathrm{~KB} 256$

$R$ (Al-Hasan) v Secretary of State for the Home Department 200519 BHRC 282 (HL)

Re Medicaments and Related Classes of Goods (No 2) 20001 WLR 700

Stansbury v Datapulse 2004 IRLR 466 (CA)

The Queen v Barnsley JJ 19602 QB 167 (CA)

\section{United States}

Likety v United States 510 US 540 (1994)

US v Morgan 313 US 409 (1941)

\section{List of abbreviations}

TSAR

Tydskrif vir die Suid-Afrikaanse Reg 